\title{
Institutional and legal provisions for the Clean Development Mechanism in South Africa
}

\author{
G. Nhamo \\ Department of Geography and Environmental Studies, \\ University of the Witwatersrand, South Africa
}

\begin{abstract}
The Kyoto Protocol (KP) cooperation mechanisms present local and national institutional and legal challenges, especially to developing countries like South Africa. One of the cooperation mechanisms in which greenhouse gases (GHGs) will be reduced from the atmosphere through the KP is the Clean Development Mechanism (CDM). The CDM permits developed countries to invest in projects that reduce GHGs in developing countries and earn carbon credits. The CDM is documented as one of the new investment avenues in developing countries with huge amounts of foreign direct investment predicted till 2012. South Africa has scored a first in having a registered CDM project in Africa. The country's CDM project implementation institutional set-up (that draws across many government departments, NGOs, civil and the private sector) presents a valuable experience not only to the African continent but other developing countries. In addition, legal provisions ranging from the National Environmental Management Act, through the Regulations for the Establishment of the Designated National Authority (DNA) and the Sustainable Development Criteria for CDM projects cannot be overemphasised. This paper therefore gives an analysis of such, including the manner in which the publics are involved in the process of CDM project approval processes.
\end{abstract}

Keywords: Kyoto Protocol, CDM, institutional and legal provision, South Africa.

\section{Introduction}

South Africa ratified the United Nations Framework Convention on Climate Change (UNFCCC) on 29 August 1997 and the related KP on 31 July 2002 (Mqadi et al [1]). Since then, the country has moved fast to establish institutions and legislation guiding conduct within one of the Kyoto Protocol (KP) flexible 
mechanisms, Clean Development Mechanism (CDM). The key institution put in place as per the dictates of the KP is the DNA, which is housed within the national Department of Minerals and Energy. New policies such as the Sustainable Development Criteria for Approval of CDM Projects have also been passed, complementing existing ones like the Constitution of 1996 and the National Environmental Management Act of 1998.

\section{Linking the UNFCCC and the CDM}

The UNFCCC aims at monitoring anthropogenic greenhouse gases (GHG) emissions. The GHGs lead to climate change that negatively affects agriculture, industry, health and socio-economic development, with a possibility of widespread population displacements in the future (Rehan and Nehdi [2]). Carbon dioxide $\left(\mathrm{CO}_{2}\right)$, methane $\left(\mathrm{CH}_{4}\right)$ and nitrous oxide $\left(\mathrm{N}_{2} \mathrm{O}\right)$ are among the chief GHGs.

Taking cognisance of the fact that climate change is a global challenge and that emission reductions are necessary regardless of their spatial location, the KP establishes three distinctive flexible mechanisms to reduce GHG emissions. These carbon trade mechanisms, which all result in credits being earned by the investing country include: (1) The Joint Implementation (JI) mechanism (Article 6), which earns the investing country emission reduction units (ERUs), (2) CDM (Article 12), which earns the investing country certified emission reductions (CERs) and (3) Emissions Trading (ET) mechanism (Article 17), which earns the investing country assigned amount units (AAUs). Given that developing (host) countries cannot engage JI and ET mechanisms and for the purposes of this paper, the following section will briefly elaborate on the CDM. Annex A of the KP presents the nature of sectors, project activities and GHGs. These and other details are presented in table 1, adopted from Conejero and Farina [3].

The CDM permits developed countries to invest in projects that reduce GHGs in developing countries like South Africa and earn carbon credits or carbon offsets (United Nations [4] Sokona et al [5] Monroy and Dutt [6]). The KP, which came into force in February 2005, compels developed countries to reduce collectively GHG by an average of $5.2 \%$ between the period $2008-2012$ based on the 1990 levels (United Nations [4]). Article 12 of the KP spells out the aim of $\mathrm{CDM}$ as assisting developing countries to achieve sustainable development as well as assisting developed countries in meeting their stipulated emission reduction targets. In addition, the CDM is subject to the authority and guidance of the Meeting of Parties (MoP) to the KP and supervised by an Executive Board. Emission reductions resulting from each CDM project are certified by operational entities designated by the MoP on the basis of: "(a) voluntary participation approved by each Party involved; (b) real, measurable, and longterm benefits related to the mitigation of climate change; and (c) reductions in emissions that are additional to any that would occur in the absence of the certified project activity" (United Nations [4]). Participation under the CDM may involve private and/or public entities. 
Table 1: $\quad$ Sectors/source categories.

\begin{tabular}{|c|c|c|c|}
\hline \multicolumn{4}{|c|}{ Greenhouse gases emissions reductions } \\
\hline Energy & Industrial processes & Agriculture & Waste \\
\hline $\mathrm{CO}_{2}-\mathrm{CH}_{4}-\mathrm{N} 2_{0}$ & $\begin{array}{c}\mathrm{CO}_{2}-\mathrm{N}_{2} \mathrm{O}-\mathrm{HFCs}- \\
\text { PFCs-SF }\end{array}$ & $\mathrm{CH}_{4}-\mathrm{N}_{2} \mathrm{O}$ & $\mathrm{CH}_{4}$ \\
\hline Fuel combustion & \multirow{4}{*}{$\begin{array}{l}\text { - Mineral products } \\
\text { - Chemical industry } \\
\text { - Production and } \\
\text { consumption of } \\
\text { halocarbons and } \\
\text { sulphur } \\
\text { hexafluoride } \\
\text { - Solvent use } \\
\text { - Others }\end{array}$} & \multirow{4}{*}{$\begin{array}{ll} & \text { Enteric fermentation } \\
\text { - } & \text { Manure management } \\
\text { - } & \text { Rice cultivation } \\
\text { - } & \text { Agricultural soils } \\
\text { - } & \text { Prescribed burning } \\
& \text { of savannas } \\
& \text { (cerrado) } \\
\text { - } & \text { Field burning }\end{array}$} & \multirow{2}{*}{$\begin{array}{l}\text { - Solid waste disposal } \\
\text { - Wastewater }\end{array}$} \\
\hline 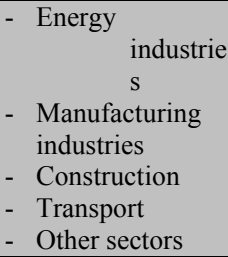 & & & \\
\hline $\begin{array}{l}\text { Fugitive emissions } \\
\text { from fuels }\end{array}$ & & & \multirow[t]{2}{*}{ - Waste incineration } \\
\hline $\begin{array}{l}\text { - Solid fuels } \\
\text { - Oil and natural } \\
\text { gas }\end{array}$ & & & \\
\hline \multicolumn{4}{|c|}{$\mathrm{CO}_{2}$ removals by sinks } \\
\hline \multicolumn{4}{|c|}{ Forestation/Reforestation } \\
\hline & Remove: & $\mathrm{O}_{2} \quad$ Emit: $\mathrm{CH}_{4}$ & \\
\hline
\end{tabular}

\section{Carbon market and financing}

The global carbon market is estimated to have grown gradually over the years. For example, both the CDM and JI appear to have increased by about 39\% between 2003 and 2004 alone. This is an equivalent of about $78 \mathrm{MtCO} 2 \mathrm{e}$ to about 108 MtCO2e of contracted emission reductions. The World Bank and other entities are at the forefront of assisting developing countries to identify appropriate technology for CDM, predict future carbon emissions and promote CDM market development (Foreign Policy In Focus [7]). The graphical representation of the global carbon market potential is depicted in figure 1 (compiled after Nygard et al [8]).

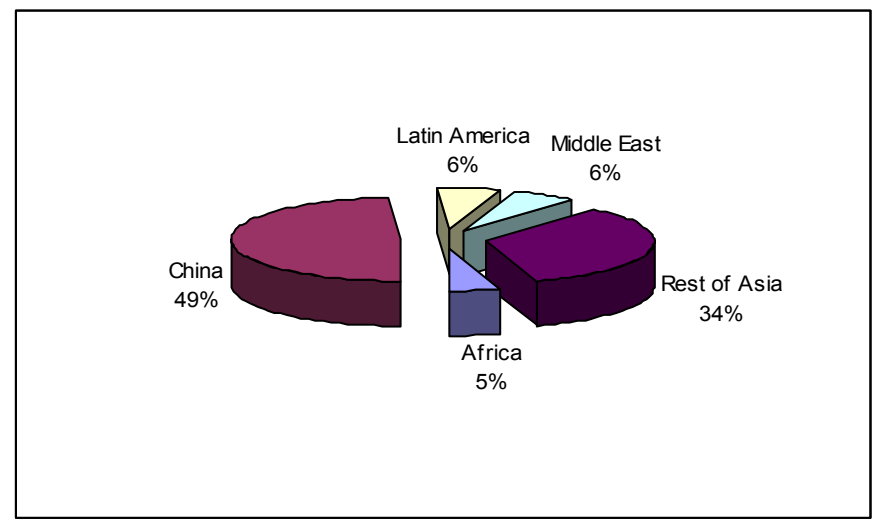

Figure 1: $\quad$ Potential global carbon market. 
Some of the major carbon financing mechanisms for international carbon trade include the EU, private sector, UNDP's Millennium Development Goals Carbon Facility and the World Bank. For the purposes of this work, the EU financing mechanism is briefly discussed.

The EU has established three key frameworks to support both the CDM and JI under the KP. These programmes include the UK Presidency of the EU [9]: Public Purchase Programmes for Project Credits, Private Sector Investment via EU Emissions Trading Scheme and Specific Capacity Building Initiatives. Through the Public Purchase Programmes EU member states plan to purchase almost 520 Million tonnes of $\mathrm{CO}_{2} \mathrm{e}$ and have so far allocated $€ 2.7$ billion to this effect. The Private Sector Investment by EU companies has been stimulated by the linking of the CDM and JI to the EU Emission Trading Scheme (ETS). The EU ETS limits the $\mathrm{CO}_{2}$ emissions of around 10,000 installations across the 25 member states of the EU. It provides for the allocation of allowances to companies, and requires companies to surrender of allowances to meet verified emissions annually. The scheme provides for the trading of allowances between companies, and since the adoption of the linking amendment provides for the use of credits from CDM and JI to meet company targets. A summary of the EU investments in the KP mechanisms is presented in figure 2 (compiled from UK Presidency of the EU [9]). Other EU national initiatives and activities are found in countries such as Belgium, France, Germany and Portugal.

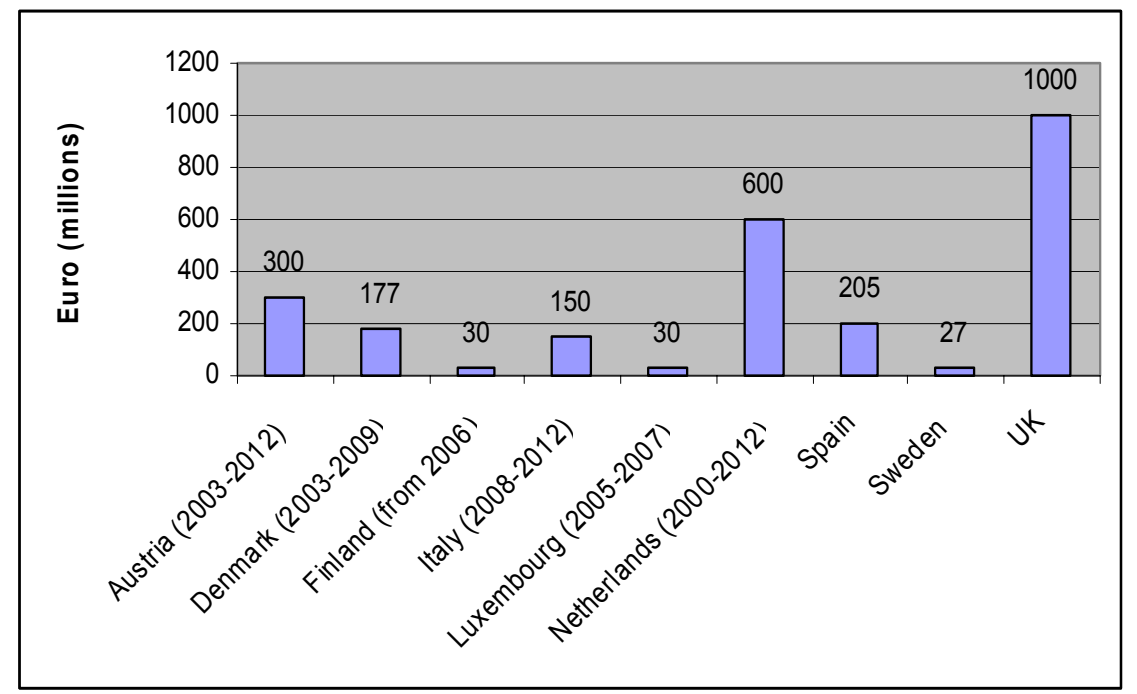

Figure 2: $\quad$ EU investment in Kyoto Protocol mechanisms. 


\section{Institutional and legal provisions for CDM in South Africa}

The institutional and legal provisions for CDM in South Africa are laid out in the Regulations for the Establishment of a DNA for the CDM of 22 July 2005 RSA [10]. These regulations have been promulgated under Section 25(3) of the National Environmental Management Act of 1998. The regulation start by defining a number of key terms and concepts among them: CDM, CDM Project, DNA, Executive Board, KP, Project proponent and Steering Committee.

From the regulations, the Director-General of the national Department of Minerals and Energy has been designated as the DNA and according to Article 2(2) of the regulations shall perform all powers and duties of the DNA. This includes delegating any such power to execute the DNA's duties. What is of interest here is that the DNA does not stand out as a separate new authority but is integral to the day-to-day duties of the Director-General. In consultation with the Steering Committee (discussed below), the DNA shall: (a) establish and apply a CDM project approval procedure, (b) evaluate CDM projects, (c) issue letters of approval, (d) facilitate effective participation by key stakeholders in the approval process of CDM projects, (e) promote CDM projects in the country, (f) monitor and report to the Minister of Minerals and Energy CDM activities and (g) deal with all donations for CDM as per the requirements of the Public Finance Management Act of 1999.

Article 4 of the regulations establish the Steering Committee (SC) for the DNA (chaired by a representative from the Department of Minerals and Energy) made up of representatives of various national departments that include, Minerals and Energy, Environmental Affairs and Tourism, Water Affairs and Forestry, Foreign Affairs, Trade and Industry, Agriculture and Land Affairs, Transport, National Treasury, Science and Technology and Health. Each of the Director-Generals from the said departments should appoint a member and an alternate to the SC. Within the SC is embedded various sub-committees and the Expert Advisory Committee. Of notable omission from the SC is the representative from the Department of Local Government and Housing. This must be a cause of concern to many who might wish to invest in the CDM as all the projects are implemented at local government level. Among some of the key responsibilities of the SC are the provision of supervision and advice concerning the running of the DNA and the setting out of evaluation and approval criteria for CDM projects and make recommendations regarding CDM projects to the DNA. One of the criteria which the SC worked on is the Sustainable Development Criteria of 2004 (Department of Minerals and Energy [11]).

\section{Sustainable development criteria}

The DNA adopted the sustainable development definition enshrined in the National Environmental Management Act (NEMA) of 1998. The NEMA defines sustainable development as "the integration of social, economic and environmental factors into planning, implementation and decision making so as to ensure that development serves present and future generations" (RSA [12]). In 
this regard, three key dimensions of sustainable development are used for the CDM project evaluation (Department of Minerals and Energy [11]): economic (does the project contribute to national development?), social (does the project contribute to social development in South Africa?), environmental (does the project conform to the National Environmental Management Act principles of sustainable development?). To facilitate measurability of the sustainable development criteria, a number of indicators were put in place (table 2).

Table 2: $\quad$ CDM project sustainable development approval criteria.

\begin{tabular}{|c|c|c|}
\hline & Criteria & Indicator (Project impact on) \\
\hline \multirow{3}{*}{ 冝 } & $\begin{array}{l}\text { Impact on local } \\
\text { environmental quality }\end{array}$ & $\begin{array}{ll}\text { - } & \text { Air quality } \\
\text { - } & \text { Water pollution } \\
\text { - } & \text { Generation or disposal of solid waste } \\
\text { - } & \text { safety, aesthetics etc) }\end{array}$ \\
\hline & $\begin{array}{l}\text { Change in usage of } \\
\text { natural resources }\end{array}$ & $\begin{array}{ll}- & \text { Community access to natural resources } \\
\text { - } & \text { Sustainability of the use of water, minerals or other } \\
\text { non-renewable natural resources } \\
\text { - } \quad \text { Efficiency of resource utilisation }\end{array}$ \\
\hline & $\begin{array}{l}\text { Impacts on biodiversity } \\
\text { and ecosystems }\end{array}$ & $\begin{array}{l}\text { Changes in local or regional biodiversity arising } \\
\text { from the project }\end{array}$ \\
\hline$\cdot \mathscr{\Xi}$ & Economic impacts & $\begin{array}{ll}- & \text { Foreign exchange requirements } \\
- & \text { Existing economic activity in the area } \\
\text { - } & \text { Cost of energy } \\
\text { - } & \text { Foreign direct investment (FDI) } \\
\end{array}$ \\
\hline 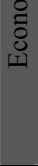 & $\begin{array}{l}\text { Appropriate technology } \\
\text { transfer }\end{array}$ & $\begin{array}{l}\text { - Positive or negative implications for the transfer of } \\
\text { technology to South Africa } \\
\text { - } \quad \text { Local skills development } \\
\text { - } \quad \text { Demonstration and replication potential of the } \\
\text { project }\end{array}$ \\
\hline & $\begin{array}{l}\text { Alignment with } \\
\text { national, provincial and } \\
\text { local development } \\
\text { priorities }\end{array}$ & $\begin{array}{l}\text { - How project is aligned with national, provincial and } \\
\text { local government objectives } \\
\text { - } \quad \text { How project is aligned with local development } \\
\text { objectives } \\
\text { - } \quad \text { Provision of, or access to, basic services to the area } \\
\text { - } \quad \text { Relocation of communities if applicable } \\
\text { Contribution to any specific objectives (e.g., energy } \\
\text { targets) }\end{array}$ \\
\hline $\begin{array}{l}\cdot \frac{\pi}{8} \\
\text { ¿ } \\
\leftrightarrow\end{array}$ & $\begin{array}{l}\text { Social equity and } \\
\text { poverty alleviation }\end{array}$ & $\begin{array}{l}\text { Employment levels (specify number of jobs } \\
\text { created/lost, duration of time employed, distribution } \\
\text { of employment opportunities, types of employment, } \\
\text { categories of employment changes in terms of skills } \\
\text { levels and gender and racial equity) } \\
\text { - } \quad \text { Social heritage } \\
\text { - } \quad \text { Provision of social amenities to communities in } \\
\text { which the project is situated } \\
\text { Contribution to the development of previously } \\
\text { disadvantaged areas }\end{array}$ \\
\hline
\end{tabular}

Source: Department of Minerals and Energy [11]. 
The three questions raised earlier are also in harmony with the new Environmental Impact Assessment Regulations of 2006 and mitigate that (Department of Minerals and Energy [11]): disturbance of ecosystems and loss of biodiversity is minimised, pollution, waste and degradation of the environment is minimised, disturbance of landscapes and sites that constitute the nation's cultural heritage is minimised, use and exploitation of non-(renewable) resources and the ecosystems is equitable and sustained, a risk averse and precautionary approach is taken, and that negative impacts on the environment and on people's environmental rights be anticipated and prevented, minimised and remedied.

In addition to the criteria spelt out in table 2 , there is a general criterion. This looks at whether the distribution of CDM project benefits are reasonable and fair. Overall, if the proposed project is deemed not to fulfil the KP requirements or contrary to the intention of the government of South Africa, the DNA reserves the right to reject it until such a time suitable amendments are made to the design (Department of Minerals and Energy [11]). However, given the complexity of numerically weighing sustainability indicators, the DNA does not use a predefined scoring system to evaluate applications.

\section{DNA project approval procedures}

The CDM project proponents have two options they can follow after conceptualising a project. They can either chose to go via the route of initial (voluntary) screening or the mandatory final submission. During the initial screening the developer submits the Project Identification (PIN) and application form that is reviewed resulting in (a) a Letter of No-Objection (leading to final submission) or (b) Letter of Objection and comments leading to a complete rejection or the revision of PIN and ultimate final submission. All this takes 30 days. During the final submission the developer includes validated Project Design Document (PDD) and application form to DNA. The PDD is made available online for public comments for 30 days whilst it simultaneously undergoes comprehensive review by the DNA. A decision is then made by the DNA to either approve (leading to the issuance of the Letter of Approval) or reject (with reasons) leaving the developer with an option to appeal to the Minister of Minerals and Energy. The appeal should be made within 60 days, the same amount of time it takes to have a decision made on the submitted PDD. Overall, either a 60 or 90 days CDM project approval process is in place. This time is critical, especially when one considers the investor competition emanating from such.

The Letter of [CDM Project] Approval stands out as one of the key legal setup for such projects in South Africa. The letter emanates from Section 40(a), Decision 17/CP.7 of the Marrakech Accords and The Marrakech Declaration of 2001 (United Nations [13]) that obligates all engaging in the CDM projects to provide: "written approval of the voluntary participation from the DAN of each party involved, including confirmation by the host party that the project activity assists in achieving sustainable development". The Letter of Approval is issued 
Table 3: $\quad$ PDD available for comment (27 April 2006).

\begin{tabular}{|c|c|c|}
\hline \multirow[t]{3}{*}{$\begin{array}{l}\text { Emfuleni Power Project } \\
\text { (Vanderbijlpark, Gauteng } \\
\text { Province) }\end{array}$} & Description & $\begin{array}{l}\text { Capturing and utilization of presently flared off- } \\
\text { gases (Coke Oven, Blast Furnace and Basic Oxygen } \\
\text { Furnace Gases) from Mittal Steel's production to } \\
\text { generate } 115 \mathrm{MW} \text { of electricity. }\end{array}$ \\
\hline & Comments & 7 February to 20 March 2006 \\
\hline & Status & Not yet registered \\
\hline \multirow[t]{3}{*}{$\begin{array}{l}\text { PetroSA Biogas to } \\
\text { Energy } \\
\text { (Duinzicht, Western } \\
\text { Cape Province) }\end{array}$} & Description & $\begin{array}{l}\text { PetroSA started to operate since } 1987 \text { as a gas to } \\
\text { liquids plant at Duinzicht. The anaerobic digestion } \\
\text { generates biogas that is flared. It is estimated that } \\
\text { the equivalent of at least } 1300 \text { gigawatthours of } \\
\text { gross heat value has been wasted and the proposed } \\
\text { project aims to utilise this to generate electricity to } \\
\text { be used onsite by PetroSA. }\end{array}$ \\
\hline & Comments & 22 December 2005 to 22 January 2006 \\
\hline & Status & Not yet registered \\
\hline \multirow[t]{3}{*}{$\begin{array}{l}\text { Lawley Fuel Switch } \\
\text { Project } \\
\text { (Johannesburg, Gaunteng } \\
\text { Province) }\end{array}$} & Description & $\begin{array}{l}\text { Conversion from coal to natural gas of the thermal } \\
\text { fuel used in clay brick baking kilns. The fuel switch } \\
\text { project is developed, financed and implemented by } \\
\text { Corobrik. Corobrik is the largest supplier of bricks } \\
\text { in South Africa and is one of the largest brick } \\
\text { producers in the world. }\end{array}$ \\
\hline & Comments & 24 October to 23 November 2005 \\
\hline & Status & Registered on 6 March 2006 \\
\hline \multirow[t]{3}{*}{$\begin{array}{l}\text { Rosslyn Brewery Fuel } \\
\text { Switching Project }\end{array}$} & Description & $\begin{array}{l}\text { Fuel switching, thus replacing the use of coal by } \\
\text { natural gas and biogas that is currently flared. }\end{array}$ \\
\hline & Comments & 24 October to 23 November 2005 \\
\hline & Status & Not yet registered \\
\hline \multirow[t]{3}{*}{$\begin{array}{l}\text { Bethlehem } \\
\text { Hydroelectricity Project } \\
\text { (Bethlehem, Free state } \\
\text { Province) }\end{array}$} & Description & $\begin{array}{l}\text { Generation of hydro-electricity which will be } \\
\text { distributed into South Africa's grid. Project involves } \\
\text { the development and operation of a } 4 \mathrm{MW} \text { of hydro } \\
\text { power generation capacity. Project will generate } \\
28.6 \mathrm{GW} / \mathrm{h} \text { annually. }\end{array}$ \\
\hline & Comments & 24 October to 23 November 2005 \\
\hline & Status & Not yet registered \\
\hline \multirow[t]{3}{*}{$\begin{array}{l}\text { Kuyasa Low-Cost Urban } \\
\text { Housing Energy Upgrade } \\
\text { Project } \\
\text { (Khayelitsha, Western } \\
\text { Cape Province) }\end{array}$} & Description & $\begin{array}{l}\text { Installation of solar water heaters, insulated ceilings } \\
\text { and compact fluorescent light bulbs in the existing } \\
2309 \text { RDP households. City of Cape Town is able to } \\
\text { receive carbon revenue from the use of renewable } \\
\text { energy technologies (thereby reducing } \mathrm{CO}_{2} \\
\text { emissions). }\end{array}$ \\
\hline & Comments & 31 March to 30 April 2005 \\
\hline & Status & Registered 2005 \\
\hline
\end{tabular}

\section{Source: Compiled from Department of Minerals and Energy [14].}

by the DNA. The procedure is that, in consultation with the SC, the DNA considers all applications within 10 days of receipt. If the DNA accepts recommendation to issue the letter from the $\mathrm{SC}$, then the Letter of Approval shall be issued within five days. The reverse (Letter of Objection) also applies and this has to be accompanied by an explanation for rejection. A Letter of Approval 
contains various information (Article 5) including letting the CDM project proponent aware that South Africa is a signatory to the KP, that participation in the project is voluntary, confirmation that the project must support sustainable development in the country, authorisation for the project proponent to participate in the CDM project and sell the title and all rights to the greenhouse gas emission reductions generated by the project and geographic location of the project. Other necessary information includes the date of expiry of the Letter of Approval. A CDM project proponent grieved by the DNA's Letter of Objection is entitled to appeal such decision in writing within 30 days and elaborate reasons thereof.

\section{CDM PDDs and public participation}

Regardless of the set sustainable development and other CDMN project evaluation criteria, the DNA took a decision to publicise (online) all CDM Project Design Documents (PDD). These PDDs are made public for 30 days upon which both interested and affected parties can comment and influence approval decisions. PDDs that were available for public comment and their status of approval are presented in table 3 .

\section{Conclusion}

This paper looked into the institutional and legal set-up concerning the implementation of CDM projects in South Africa. The work revealed that the Director-General of the Department of Minerals and Energy has been designated the DNA. The DNA receives professional and other support from an interdepartmental Steering Committee. It emerged that on average a 60 or 90 day CDM project approval process is in place depending on whether the proponent chooses to take the route of an initial (voluntary) screening process (30 days) or just goes for the final submission (60 days). It also came out that the Department of Local Government and Housing was omitted from the designate members of the Steering Committee. Overall, the paper indicates that South Africa has made great steps towards putting in place plausible Sustainable Development Criteria for CDM projects as well as attracting investment in this direction. By the time of writing, two CDM projects had been registered (one in 2005 and the other in 2006) with many more at various stages of approval.

\section{References}

[1] Mqadi, L., Winkler, H. \& Churie Kallhauge, A., South Africa beyond Kyoto, South-South-North/Energy Research Centre University of Cape Town/Swedish Energy Agency: Cape Town, pp. 2 4, 2004.

[2] Rehan, R. \& Nehdi, M., Carbon dioxide emissions and climate change: Policy implications for the cement industry. Environmental Science and Policy 2005, 8, pp. 105. 
[3] Conejero, M.A. \& Farina, E., Carbon market: Business incentives for sustainability, PENSA: Sao Paulo, pp. 6-8, 2003.

[4] United Nations, Kyoto Protocol to the United Nations Framework Convention on Climate Change, United Nation Secretariat: Kyoto, pp. 13-14, 1997.

[5] Sokona, Y., Humphreys, S. \& Thomas, J.P., Sustainable development: a centrepiece of the Kyoto Protocol - an African perspective (Chapter 3). Towards Equity and Sustainability in the Kyoto Protocol, ed. K. Hultcrantz, Stockholm Environment Institute: Stockholm, pp. 31-33, 1999.

[6] Monroy, M.G. \& Dutt, G.T., CDM market development: lessons and views from host country entities. Carbon Market Update for CDM Host Countries, 2, pp. 1-2, 2005.

[7] Foreign Policy In Focus, A carbon rush at The World Bank, Foreign Policy In Focus: Washington DC, pp. 1-6, 2005.

[8] Nygard, J., Murray, A. \& Streck, C., Clean Development Mechanism in China: taking a proactive and sustainable approach. The Sino Sphere Journal, 8(1), pp. 5-6

[9] UK Presidency of the EU, EU investment in the Kyoto Protocol Mechanisms, European Union: Brussels, pp. 1-17, 2005.

[10] RSA., National Environmental Management Act, 1998 Regulations for the Establishment of a Designated National Authority for the Clean Development Mechanism, Government Printer: Cape Town, pp. 3-7, 2005.

[11] Department of Minerals and Energy. Sustainable Development Criteria for Approval of Clean Development Mechanism Projects by the Designated National Authority of the CDM. Pretoria: Government Printer, pp. 1-4, 2004.

[12] RSA. National Environmental Management Act (Act No. 107 of 1998). Pretoria: Government Printer, pp. 10-11, 1998.

[13] United Nations, The Marrakesh Accords and The Marrakesh Declaration, United Nation Secretariat: Marrakesh, pp. 20-21, 2001.

[14] Department of Minerals and Energy, www.dme.gov.za/home.asp?menu=events/events.htm, 09-04-2006 